\title{
RESEARCH ARTICLE \\ EFFECT OF CADMIUM CHLORIDE ON THE HAEMATOLOGICAL PROFILES OF THE FRESHWATER ORNAMENTAL FISH, CYPRINUS CARPIO KOI (LINNAEUS, 1758)
}

\author{
A. Jawahar Ali1 ${ }^{*}$, N. Jalaluddin Akbar' ${ }^{1}$, M.S. Arun Kumar ${ }^{1}$, S. Vijayakumar ${ }^{1}$, B. Akbar John² \\ ${ }^{1}$ Unit of Aquaculture and Aquatic Toxicology, PG \& Research Department of Zoology, The New College, Chennai 600014, India \\ ${ }^{2}$ Institute of Oceanography and Maritime Studies (INOCEM), Kulliyyah of Science, International Islamic University Malaysia (IIUM), Kuantan, \\ Pahang, Malaysia \\ *Corresponding author: jawahar alidr@yahoo.co.in
}

This is an open access article distributed under the Creative Commons Attribution License, which permits unrestricted use, distribution, and reproduction in any medium, provided the original work is properly cited

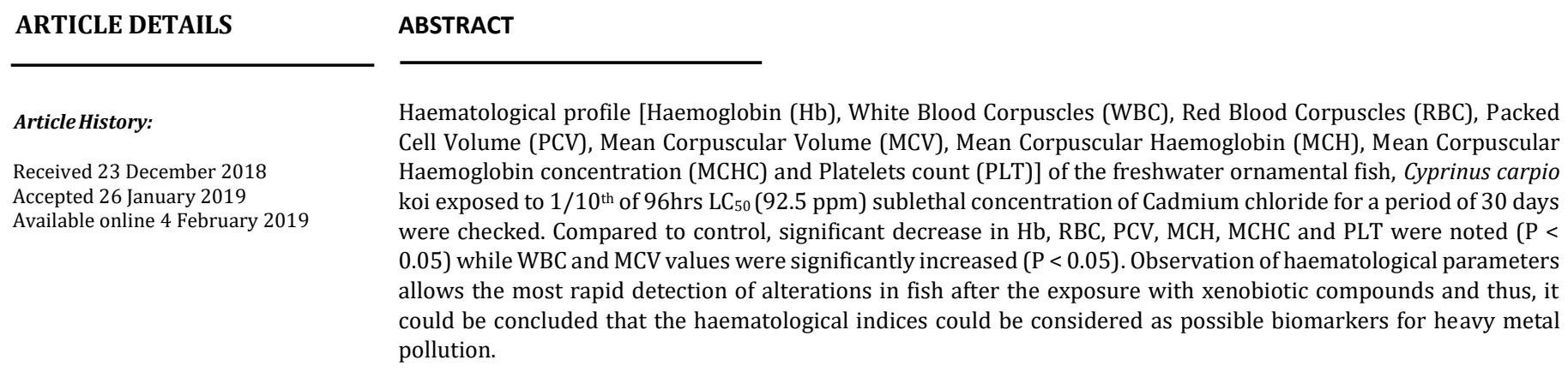

\section{KEYWORDS}

Cyprinus carpio koi, Cadmium chloride, Haematology, Heavy metal pollution

\section{INTRODUCTION}

Intensive agricultural operations and industrial activities release enormous amount of heavy metals into aquatic ecosystem. The heavy metals after reaching the aquatic habitats cause serious problem due to bioacummulation, biomagnifcation in the food chain and toxicity to the organisms [1-4]. The toxicity of heavy metals to aquatic organisms particularly on freshwater fishes is well documented [5-13]. Cadmium (Cd) is one of the biologically non-essential, most toxic heavy metal widely used in $\mathrm{Ni}-\mathrm{Cd}$ batteries manufacture, metal and mining, dentistry etc. because of its noncorrosive nature [14].

Cadmium is usually rare in natural form and is concentrated in argillaceous and shale deposits as green rocks (Cds) or otavite $\left(\mathrm{CdCO}_{3}\right)$ and it is naturally associated with zinc, lead or copper in sulphide form [15]. It has been listed in the 'black list' of European community and classified as b-class (soft) metal $[16,17]$. Due to its non-biodegradable nature; it gets into the aquatic ecosystems and ultimately enters the human and animal's blood stream [18]. The major sources of contamination include electroplating, paper, PVC manufactures, Plastic, paint pigments, fumicides and ceramic industries [19]. It is also entering into aquatic bodies through sewage sludge and with runoff from agricultural fields, as it is one of the major components of the phosphate fertilizers [20]. In human, $\mathrm{Cd}$ has been found to cause wide range of biochemical and physiological dysfunctions as manifested in the forms of various diseases viz. Itai-itai, liver malfunction, inflammation, diabetes, Parkinson's disorder, respiratory tract cancer, kidney and prostate cancer [21-24]. In fishes and shrimps, it causes impairment of reproductive activity and disrupts endocrine functions when they exposed even at low concentrations $[25,26]$. The accumulation of $\mathrm{Cd}$ has also been well described in different tissues of fishes $[27,28]$.
Haematological indices have been recognized as valuable tools for evaluation of fish physiological status, the changes of which depend on fish species, age, cycle of sexual maturity and diseases [29-35]. The toxicity of Cadmium to freshwater fishes has been well reported. For example, anaemic condition was reported in Channa punctatus and Oreochromis mossambicus exposed to different doses of Cadmium [36,37]. A researcher observed increased leucocytes, neutrophils and eosinophils (leukocytosis, neutrophilia and eosinophilia) in Cyprinus carpio exposed to sublethal concentrations of $\mathrm{Cd}$ [38]. Changes in serum biochemical parameters due to liver, gill and kidney dysfunction was reported by a researcher in Oreochromis niloticus exposed to Cadmium [39]. It also acts as an immunosuppressant in common carp (C. carpio), Oreochromis aureus, $O$. niloticus and Ictalurus melas, respectively [40-42]

Fishes were proved to be significant bioindicators of the aquatic environment so- called ecological integrity $[43,44]$. It can provide quantitative information on the ecological integrity and its health. As ornamental fishes contribute significantly to the freshwater aquaculture of India and due to their species richness, they have been selected as suitable bioindicators for heavy metal pollution. Amongst ornamental fishes, $C$. carpio koi has the highest market value and hence it has been selected as the bioindicator model for $\mathrm{Cd}$ pollution. Though several studies have been carried out to document the toxic effect of heavy metals in general and in $\mathrm{Cd}$ in particular on few ornamental and marine fishes, the studies on the effect of pollutants on the hematological profile is still scanty [45-47]. Hence, the present investigation was aimed to evaluate the toxic effects of $\mathrm{CdCl}_{2}$ on the haematological indices of the freshwater ornamental fish, $C$. carpio koi.

\section{MATERIAL AND METHODS}




\subsection{Experimental setup}

The freshwater ornamental fish, Cyprinus carpio koi $(11.56 \pm 1.28 \mathrm{~cm}$ length and approximately $25.84 \pm 6.0 \mathrm{~g}$ weight) were procured from Solai Aquarium fish farm, Kolathur, Chennai, Tamil Nadu, India. The test organisms were transported to the laboratory in plastic bags with least disturbance and were washed with $0.1 \% \mathrm{KMnO}_{4}$ solution to get rid of dermal infection. Healthy fishes were selected and acclimated to the laboratory conditions (12hrs light/ $12 \mathrm{hrs}$ dark) by introducing them in a plastic tub $(80 \times 30 \times 40 \mathrm{~cm})$ using chlorine free tap water with adequate aeration for a period of 15 days. The water quality conditions such as temperature $\left(27 \pm 1^{\circ} \mathrm{C}\right) \mathrm{pH}(7.5)$; Dissolved Oxygen $(6.7 \mathrm{mg} / \mathrm{l})$; Salinity $(0.5$ $\pm 0.05 \mathrm{ppt}$ ); Total hardness $(255.0 \mathrm{mg} / \mathrm{l})$; Nitrate $(1.6 \mathrm{mg} / \mathrm{l})$; Chloride (27.0 mg/l); Ammonia (0.058 mg/l); BOD (5.8 mg/l); COD (14.7 mg/l) and Total solid $(1.7 \mathrm{~g} / \mathrm{l})$ were maintained. Commercial fish feed (Ocean free) was provided thrice a day satiation. Water was exchanged $100 \%$ on daily basis; cleaning of aquaria was carried out to remove fecal matter and food remains.

\subsection{Chemical}

Analytical grade Cadmium chloride $\left(\mathrm{CdCl}_{2}\right)$ was obtained from Merck (Merck Company, Darmstadt, Germany, Glaxo India Limited, Bombay, India (No. 17584) and used without further purification.

\subsection{Experimental exposure}

The $\mathrm{LC}_{50}$ values of Cadmium chloride was calculated by Probit's method [48]. The $96 \mathrm{hrs} \mathrm{LC}_{50}$ for $\mathrm{CdCl}_{2}$ was found to be $925 \mathrm{ppm}$ to C. carpio koi. After determining the $\mathrm{LC}_{50}$ values, 20 fishes of two batches were introduced into $35 \mathrm{~L}$ plastic tubs containing $25 \mathrm{~L}$ of water; experiments were carried out in triplicates. Group I with 20 fishes was kept as control and Group II fishes $(\mathrm{N}=20)$ were exposed to $1 / 10^{\text {th }}$ of $96 \mathrm{hrs} \mathrm{LC}_{50}(92.5$ $\mathrm{mg} / \mathrm{L}$ )) sublethal concentration of $\mathrm{CdCl}_{2}$. The concentration of the toxicant in the water was renewed daily. During the period of continuous exposure to the $\mathrm{CdCl}_{2}$, the fish were fed with commercial feed on every alternate day at a rate of $3 \%$ body weight. The control and treated fishes were kept under continuous observation for 30 days under aerated condition. At the end of $15^{\text {th }}$ and $30^{\text {th }}$ days, 10 fishes were collected from each tub and the blood samples were collected through cardiac puncture using $1 \mathrm{ml}$ dispovan heparinized syringes and stored in EDTA vials.

\subsection{Haematological analysis}

Haematological profiles were estimated by following the standard procedures of a scholar [49]. Haemoglobin $(\mathrm{Hb})$ was estimated by the method of another scholar [50]. Red Blood Corpuscles (RBC) and White Blood Corpuscles (WBC) were enumerated in the Neubauer Haemocytometer (Improved Neubauer Weber Scientific Ltd.) following the method of a previous researcher [51]. Packed Cell Volume (PCV) was determined adopting the method of another researcher [52]. The red blood cell indices that include Mean Corpuscular Volume (MCV), Mean Corpuscular Haemaglobin (MCH) and Mean Corpuscular Haemoglobin Concentration (MCHC) were calculated using the formula of a researcher [53]. Platelet (PLT) count was performed following the method of [54].

\subsection{Statistical analysis}

Significant differences between the control and experimental group were calculated by using Analysis of Variance (ANOVA) test followed by Tukey's post-hoc test. Data expressed in Mean \pm SD. All analysis was done using IBM SPSS Statistical Package (Ver. 20).

\section{RESULTS}

The exposure of freshwater ornamental fish, Cyprinus carpio koi to sublethal concentration of $\mathrm{CdCl}_{2}$ for 15 and 30 days caused significant alterations in haematological profiles as shown in Table-1.

\subsection{Estimation of Haemoglobin}

As shown in Table 1, haemoglobin contents of control fishes after 15 and 30 days were $8.40 \pm 0.10$ and $10.20 \pm 0.20 \mathrm{~g} / \mathrm{dl}$, respectively, whereas in treated fishes, the $\mathrm{Hb}$ contents after 15 and 30 days were $7.50 \pm 0.10$ and $5.36 \pm 0.05 \mathrm{~g} / \mathrm{dl}$, respectively. The percentage changes over control were 10.71 and $-47.45 \%$, respectively. One-way ANOVA followed by Tukey's test revealed that after $15^{\text {th }}$ and $30^{\text {th }}$ days of exposure there was significant difference $(\mathrm{P}<0.05)$ between control and treated groups.

\subsection{Total WBC count}

The WBC counts in control fishes after 15 and 30 days showed an average number of $1.69 \pm 0.02$ and $1.87 \pm 0.01$ thousand cells $/ \mathrm{mm}^{3}$ of blood, respectively, whereas the treated fishes showed a significant increase in WBC count $(\mathrm{P}<0.05)$. The WBC counts of treated fishes after 15 and 30 days were $2.19 \pm 0.05$ and $3.16 \pm 0.01$ thousand cells $/ \mathrm{mm}^{3}$, respectively. The percentage variations from the control group were +29.58 and $+68.98 \%$ of cells, respectively.

\subsection{Total RBC count}

The average number of RBCs in control fishes after 15 and 30 days were estimated to be $1.49 \pm 0.01$ and $2.10 \pm 0.1$ million cells $/ \mathrm{mm}^{3}$ of blood, respectively. The treated fishes showed a significant decrease in RBC counts $(\mathrm{P}<0.05)$. The RBC counts of treated fishes after 15 and 30 days were $1.21 \pm 0.02$ and $0.88 \pm 0.01$ million cells $/ \mathrm{mm}^{3}$ of blood respectively. The percentage changes over the control were- 18.79 and $-58.09 \%$ of cells, respectively.

\subsection{Packed Cell Volume (PCV)}

PCV levels of control fishes after 15 and 30 days were found to be $10.46 \pm 0.15$ and $12.62 \pm 0.01 \%$, respectively. In treated fishes, the PCV levels after 15 and 30 days were $8.43 \pm 0.11$ and $6.27 \pm 0.05 \%$, respectively. The percentage changes over the control were -19.40 and $-50.31 \%$, respectively. One-way ANOVA followed by Tukey's test revealed that after $15^{\text {th }}$ and $30^{\text {th }}$ days of exposure, there was a significant difference $(\mathrm{P}<0.05)$ between control and $\mathrm{CdCl}_{2}$ treated group.

\subsection{Mean Corpuscular Volume (MCV)}

MCV levels of control fishes after 15 and 30 days were $82.36 \pm 0.01$ and $85.23 \pm 0.01 \mathrm{fl}$, respectively. The treated fishes showed a significant increase in MCV levels $(\mathrm{P}<0.05)$. The MCV levels of treated fishes after 15 and 30 days were $84.63 \pm 0.02$ and $90.35 \pm 0.01 \mathrm{fl}$, respectively. The percentage changes over the control were +2.75 and $+3.67 \%$, respectively.

\subsection{Mean Corpuscular Haemaglobin (MCH)}

The MCH levels of control fishes during 15 and 30 days were $32.84 \pm 0.01$ and $35.48 \pm 0.005 \mathrm{pg}$, respectively. In the treated fishes, the MCH levels were $30.22 \pm 0.01$ and $27.62 \pm 0.02 \mathrm{pg}$, respectively. The percentage changes over the control were -7.97 and $-22.15 \%$, respectively. One-way ANOVA followed by Tukey's test revealed that after $15^{\text {th }}$ and $30^{\text {th }}$ days of exposure, there was a significant difference between control and $\mathrm{CdCl}_{2}$ treated group $(\mathrm{P}<0.05)$.

\subsection{Mean Corpuscular Haemoglobin Concentration (MCHC)}

MCHC levels of control fishes after 15 and 30 days were $40.66 \pm 0.01$ and $44.56 \pm 0.02 \%$, respectively. The treated fishes showed a significant decrease in MCHC $(\mathrm{P}<0.05)$. The MCHC levels of treated fishes after 15 and 30 days were $39.77 \pm 0.01$ and $37.50 \pm 0.2 \%$, respectively. The percentage changes over the control were -2.18 and $-15.85 \%$, respectively.

\subsection{Platelet Count}

The platelet (PLT) counts of control fishes after 15 and 30 days were $5.95 \pm 0.005$ and $7.87 \pm 0.01110^{9} / \mathrm{l}$, respectively. In the treated fishes, the platelet counts after 15 and 30 days were $3.96 \pm 0.005$ and $3.53 \pm 0.015$ $10^{9} / \mathrm{l}$, respectively. The percentages changes over the control were -33.44 and $-55.14 \%$, respectively. One-way ANOVA followed by Tukey's test revealed that there was a significant difference between control and $\mathrm{CdCl}_{2}$ treated group $(\mathrm{P}<0.05)$.

\section{DISCUSSION}

Hematological parameters can be used as a diagnostic tool in toxicology to detect the fish health status under different stress conditions like diseases, hypoxia and exposure to heavy metals and pollutants [55-59]. Heavy metals have a tendency to accumulate in different tissues of fish resulting in the reduction of DNA, RNA, protein, carbohydrate and lipids contents of 
the cell [60-63]. In the present investigation, the haematological indices such as Hb, WBC, RBC, PCV, MCV, MCHC and PLT levels were observed in the fish (C. carpio koi) exposed to $\mathrm{CdCl}_{2}$. The haematological parameters like Hb, RBC, PCV, MCH, MCHC and PLT were significantly ( $<<0.05)$ decreased whereas the profiles like WBC and MCV values were significantly $(\mathrm{P}<0.05)$ increased when compared to that of control (Table 1).

As shown in Table 1 , the $\mathrm{Hb}$ content shows a decline in the heavy metal treated fishes. It was found to be corresponding to the lowering of RBC and might be due to the impairment of haemopoietic system as a result it leads to anemia associated with erythropenia. The results of the present study support the work carried out by a researcher who observed the decrease in $\mathrm{Hb}$ concentration in the blood of Eel and Perch after short-term and long-term exposure to Cadmium [64]. According to a group of researchers, the fish exposed to Cadmium shows a significant decrease in blood iron level caused by the deficiency of intestinal absorption which might be the reason for reduction in $\mathrm{Hb}$ concentration $[65,66]$. A researcher suggested that the decline in $\mathrm{Hb}$ content in fish exposed to toxicants might also be due to the inhibitory effect of the toxic substance on the enzyme system responsible for the $\mathrm{Hb}$ synthesis [67]. Prolonged decrease in $\mathrm{Hb}$ content impaired an oxygen supply, blood dyscrasia and degeneration of the erythrocytes leading to hypoxia conditions in fishes exposed to toxicants [68-71]. Significant reduction in the $\mathrm{RBC}$ and $\mathrm{Hb}$ in fishes exposed to heavy metals was also reported by earlier studies [72-75].

The sudden spurt in WBCs of the treated fish in the present work might be due to the stimulation of lymphopoiesis and release of lymphocytes from lymphomyeloid tissue to combat the toxicant stress. Similarly, the findings of several researchers suggested that when the pollutant enters the animal tissues, it could have combined with biochemical constituents of the cells and form xenobiotics, due to these reactions, the production of WBCs may be increased and there by the process of elimination of toxic substances from the tissues would have been attempted to prevent the animals from fatal condition [76-84].

The decrease in RBC count noticed in the present study might be due to the destructive action of heavy metal on the peripheral red cells. As a result, the viability of cells is affected. Similar observations were also reported in the gold fish Carassius auratus exposed to Nickel [85]. In contrast, a researcher observed an increase in RBCs and $\mathrm{Hb}$ in freshwater fish, Prochilodus scrofa exposed to Copper. However, the damaging effects on the RBCs may be secondary, resulting from primary action of the toxicant on the erythropoietin tissues due to which there exists a failure in red cell production [86]. In general, the reduction in the levels of RBCs and PCV (due to the destruction of RBC or erythroblastosis) results in anaemia [87].

The anaemic condition in fish may also be attributed to low number of RBCs or too low levels of $\mathrm{Hb}$ in the RBCs. A researcher suggested that the anemic condition was probably not due to the increased destruction of erythrocytes, since the spleen size was unchanged but might be due to a reduced RBC synthesis or release of blood cells into the circulation [88]. A previous researcher noticed a decrease in the number of erythroblastsproerythrocytes when goldfish, C. auratus and rainbow trout, Salmo gairdneri were exposed to Cadmium [89]. It was also noticed that the cadmium caused a decreased erythropoiesis and impaired the production of RBCs. Additionally, a researcher stated that the haemolysis of blood took place by stimulatory effects of toxicants in RBCs, which altered the permeability of the cell membrane or increased mechanical fragility [90]. The decline in the level of $\mathrm{Hb}, \mathrm{PCV}$ and platelet count of $C$. carpio koi during exposure to $\mathrm{CdCl}_{2}$ clearly implied a haemodilution mechanism probably due to impaired osmoregulation or gill damage. Similar results with significant decrease of RBCs, Hb, PCV and platelet counts in fishes exposed to different heavy metals have been reported earlier by a previous researcher [91-94].

The haematological indices like MCV, MCH and MCHC provide more information on size, relationship, form and $\mathrm{Hb}$ constants of erythrocytes. Furthermore, these indices serve as criterion for morphological studies of anemia belongs to Normocyte, Macrocyte or Microcytic type. The elevation of $\mathrm{MCV}$ and reduction of $\mathrm{MCH}$ and $\mathrm{MCHC}$ in the present study might be due to defensive mechanism against the Cadmium toxicity. This falls in line with the findings of a researcher, who had recorded similar changes in $\mathrm{MCV}, \mathrm{MCH}$ and MCHC of L. rohita treated with Chromium.
Significant increase in MCV and WBC count implies that the anemia is of Macrocytic type $[95,96]$. The increase in MCV may be due to swelling of $\mathrm{RBC}$ as a result of hypoxia condition or Macrocytic anaemia in the fishes exposed to heavy metals as suggested by a researcher [97]. The MCH and MCHC were considered as good indicators for red blood swelling. In the present study, the decreased MCH and MCHC might be due to the release of proerythrocytes containing low haemoglobin in circulation. Meanwhile, the significant decline in $\mathrm{MCH}$ and $\mathrm{MCHC}$ values might be due to Hypochromic anemia.

\section{CONCLUSION}

This study clearly indicates that $\mathrm{CdCl}_{2}$, a biologically non-essential toxic heavy metal, caused severe anemia and alterations in haematological profiles under laboratory conditions. Therefore, the haematological parameters are considered as most sensitive in monitoring toxicity of Cadmium and other heavy metals especially at sublethal doses. Further, the fish C. carpio koi may be considered as a suitable model to detect the toxicity of xenobiotics drained or contaminated in the aquatic ecosystems. The present basic information of the haematological parameters would serve as a useful tool for further ecological assessment and monitoring of these aquatic organisms, which is considered to be an important food source for human beings.

\section{ACKNOWLEDGEMENTS}

Authors are thankful to Management, Principal and Head of the Department of Zoology, The New College, Chennai-14, Tamil Nadu, India for providing necessary facilities.

\section{REFERENCES}

[1] Yousafzai, A.M., Siraj, M., Ahmed, H., Chivers, D. 2012. Bioaccumulation of heavy metals in Common carp: Implications for Human Hlth Pak J Zool, 44(2), 489-94.

[2] Ibemenuga, Nwamaka, K. 2013. Bioaccumulation and toxic effects of some heavy metals in freshwater fishes. Ani Res Int, 10(3), 1792-98.

[3] Govind, P., Madhuri, S. 2014. Heavy metals causing toxicity in animals and fishes. Res J Ani Vet Fis Sci, 2(2), 17-23.

[4] Ahmed, Q., Benzer, S., Elahi, N. 2015. Seasonal variations of heavy metal concentration in Sardinella sindensis (Day, 1878) from Balochistan coast. J Cos Lif Med, 3(5), 337-40.

[5] Palacios, P.S., Biagianti-Risbourg, S., Vernet, G. 2000. Biochemical and (ultra)structural hepatic perturbation of Brachydanio rerio (Teleostei, Cyprinidae) exposed to two sublethal concentrations of copper sulphate. Aquat Toxicol, 50, 109-24.

[6] Karatas, S., Kaley, M. 2002. Accumulation of lead in the gill, liver, kidney and brain tissues of Tilapia zilli. Turk J Veteri Anim Sci, 26, 471-77.

[7] Gul, S., Kurutas, E.B., Yilidiz, E., Sahan, A., Doran, F. 2004. Pollution correlated modifications of liver antioxidant systems and histopathology of fish (Cyprinidae) living in Seyhan Dam Lake, Turkey. Env Int, 30, 60509.

[8] Vutukuru, S.S. 2005. Acute effect of hexavalent chromium on survival, oxygen consumption, haematological parameter and some biochemical profiles of the Indian Major carp, Labeo rohita. Int J Environ Res Public Hlth, 2(3), 456-62.

[9] Palaniappan, P.L.R.M., Vijayasundaram, V. 2008. Fourier transform infrared study of protein secondary structural changes in the muscle of Labeo rohita due to arsenic intoxication. Food Chem Toxicol, 46, 3534-39.

[10] Asrar Sheriff, M., Sultan Mohideen, A.K., Altaff, K. 2012. Lead induced toxicity on the gills of the Indian major carp: Labeo rohita. Int J Res Fish Aqu, 2(3), 38-40.

[11] Srivastav, A.K., Rai, R., Suzuki, N., Mishra, D., Srivastav, S.K. 2013. Effects of lead on the plasma electrolytes of a freshwater fish, Heteropneustes fossilis. Int Aqua Res, 5(4), 1-7. 
[12] Arya, A. 2014. Evaluation of biochemical and histochemical changes following the combined treatment of Mercury and Cadmium in a freshwater cat fish, Clarias batrachus (Linn). Int J Phar Pharm Sci, 6(10), 356-58.

[13] El Sayed, A.M., Shokr. 1932. Effect of water pollution on Oreochromis niloticus. J Chem Pharm Res, 7(3), 1932-36.

[14] Shoba, K., Poornima, A., Harini, P., Veeraiah, K. 2007. A study on biochemical changes in the fresh water fish, Catla catla (Hamilton) exposed to heavy metal toxicant Cadmium chloride. J. Sci Eng Tech, 1, 4-5.

[15] Cameron, R.E. 1992. Guide to site and soil description for hazardous waste site characterization. In: Metals, Vol 1. Environmental Protection Agency, Las Vegas, EPA/600/4-91/029.

[16] Mason, C.F. 1996. Biology of freshwater pollution, 3rd edn., Longman, U.K, 1-4.

[17] Frausto da Silva, J.J.R., Williams, R.J.P. 1991. The biological chemistry of the elements: the inorganic chemistry of life. Clarendon, Oxford, 53152 .

[18] Holis, L., McGeer, J.C., Mc Donald, D.G., Wood, C.M. 1999. Cadmium accumulation, gill $\mathrm{Cd}$ binding, acclimation and physiological effects during long term sublethal $\mathrm{Cd}$ exposure in rainbow trout. Aquat Toxico, 46, 10119.

[19] Gupta, D.K., Rai, U.N., Singh, A., Inouhe, M. 2003. Cadmium accumulation and toxicity in Cicer arietinum L. Poll Res, 22, 457-63.

[20] Cherian, M.G., Goyer, R.A. 1989. Cadmium toxicity: Comments. Toxicology, 3, 191.

[21] Linder, M. 1985. Nutritional Biochemistry and Metabolism, Elsevier Science Publishing Co., Inc, New York.

[22] Bernard, A., Lauwerys, R. 1986. Cadmium in human populations. Experimentia, 40, 143-52.

[23] ATSDR (Agency for Toxic Substances and Disease Registry). 1989. Toxicological profile for Cadmium. ATSDR/US Public Health Service, ATSDR/TP- 88/08.

[24] Borane, V.R. 2013. Protective role of ascorbic acid on the induced changes in haematology of the freshwater fish, Channa orientalis (Schneider). Adv App Sci Res, 4(2), 305-08.

[25] Hatakeyama, S., Yasuno, M. 1981. A method for assessing chronic effects of toxic substances on the midge Paratanyarsus parthenogeneticus - effects of copper. Arc Environ Contam. Toxicol, 10, 705-715.

[26] Revathi, P., Vasanthi, L.A., Munuswamy, N. 2011. Effect of Cadmium on the ovarian development in freshwater prawn Macrobrachium rosenbergii (De Man). Ecotox Environ Safe, 74, 623-29.

[27] Jayakumar, P., Paul, V.I. 2006. Patterns of Cadmium accumulation in selected tissues of the catfish Clarias batrachus (Linn.) exposed to sublethal concentration of Cadmium chloride, Veterinarski Arhiv, 76(2), 167-77.

[28] Moiseenko, T.I. 2015. Impact of geochemical factors of aquatic environment on the metal bioaccumulation in fish, Geochem Int, 53(3), 213-23.

[29] Vinodhini, R., Narayanan, M. 2009. The impact of toxic heavy metals on the haematological parameters in common carp (Cyprinus carpio L.). Iran J environ Hlth Sci Eng, 6(1), 23-28.

[30] Kayode, S.J., Shamsusideen, A. 2010. Haematological studies of Oreochromis niloticus exposed to diesel and drilling fluid in Lagos, Nigeria. Int J Bio Con, 2(5), 130-33.

[31] Satheeshkumar, P., Ananthan, G., Senthi Kumar, D., Jagadeesan, L. 2011. Haematology and biochemical parameters of different feeding behavior of teleost fishes from Vellar Estuary, India. Comp Clin Pathol, DOI 10.1007/s00580-011-1259-7.

[32] Summarwar, S., Verma, S. 2012. Study of selected haematological indices of freshwater fish from Bisalpur reservoir. I J Fundament Apl Lif Sci, 2(2), 51-54.

[33] Fazio, F., Marafioti, S., Arfuso, F., Piccione, G., Faggio, C. 2013. Comparative study of the biochemical and haematological parameters of four wild Tyrrhenin fish species. Veterinarni Medicina, 58(11), 576-81.

[34] Soundararajan, M., Veeraiyan, G., Samipillai, S.S. 2014. Effect of heavy metal Arsenic on haematological parameters of freshwater fish, Tilapia mossambica. Int J Modn Res Revs, 2(3), 132-35.

[35] Mallesh, B., Pandey, P.K., Kumar, K., Vennila, A., Kumar, S. 2015. Bioconcentration of hexavalent chromium in Cirrhinus mrigala (Ham 1822): effect on haematological parameters. J Bio Earth Sci, 5(1), 59-67.

[36] Karuppasamy, R., Subathra, S., Puvneswari, S. 2005. Haematological responses to exposure to sublethal concentration of Cadmium in air breathing fish, Channa punctatus (Bloch). J Environ Biol, 26, 123-28.

[37] Wu, S.M., Deng, A.N. 2006. Effect of cadmium on hematological functions in tilapia (Oreochromis mossambicus). Bull Environ Contam Toxicol, 76, 891-98.

[38] Schuwerack, P.M., Lewis, J.W., Hoole, D. 2003. Cadmium-induced cellular and immunological responses in Cyprinus carpio infected with the blood parasite, Sanguinicola inermis. J Helm, 77(4), 341-350.

[39] Oner, M., Atli, G., Canli, M. 2008. Changes in serum biochemical parameters of freshwater fish Oreochromis niloticus following prolonged metal (Ag, Cd, Cr, Cu, Zn) exposures. Environ Toxicol Chem, 27(2), 360-66.

[40] Patrick, T.K., Yoke, M., Ming, K.W. 1993. The effects of short-term acute cadmium exposure on blue tilapia, Oreochromis aureus. Environ Biol Fish, 37, 67-74.

[41] Viola, A., Pregnolato, G., Albergoni, V. 1996. Effect of in vitro Cadmium exposure on natural killer (NK) cells of catfish, Ictalurus melas. Fish Shell Immunol, 6(3), 167-72.

[42] Małgorzata, W. 2005. Stress in fish haematological and immunological effects of heavy metals. Electronic J Ichthyol, 1(35), 35-41.

[43] Karr, J.R. 1993. Defining and assessing ecological integrity: beyond water quality. Environ Toxicol Chem, 12(9), 1521-31.

[44] Schiemer, F. 2000. Fish as indicators for the assessment of the ecological integrity of large rivers. In assessing the ecological integrity of running waters. Springer Netherlands, 271-78.

[45] James, R., Sampath, K. 2003. Edward DS. Copper toxicity on growth and reproductive potential in an ornamental fish, Xiphophorus helleri. Asian Fisheries Sci., 16, 317-26.

[46] Messaoudi, I., Barhoumi, S., Said, K., Kerken, A. 2009. Study on the sensitivity to Cadmium of marine fish Salaria basilisca (Pisces: Blennidae). J Environ Sci, 21, 1620-24.

[47] Kabilan, N., Chezhian, A., Sureshkumar, T., Senthamilselvan, D., Ezhilmathy, R., Rajalakshmi, K., Suresh, E., Varadharajan, D. 2013. The combined effects of Mercury chloride and Cadmium chloride metals on plasma electrolytes of a fish, Lates calcarifer. Int J Analy Bioanaly Chem, 3(4), 183-88.

[48] Finney, D.J., Probit. 1964. Analysis, 2nd Edn. Cambridge university press, London.

[49] Blaxhall, P., Daisley, K.W. 1973. Routine haematological methods for use with fish blood. J Fish Biol, 5, 771-81.

[50] Brown, L.J. 1980. A new instrument for the simultaneous measurement of total hemoglobin \% carboxyhemoglobin \% 
methemoglobin and oxygen content in whole blood. Trans BME, 27, 13238.

[51] Baker, F.J., Silverton, R.E. 1982. Introduction to Medical Laboratory Technology. $5^{\text {th }}$ ed. Butterworth and Co (Publishers) Ltd. London, 549.

[52] Snieszko, S.F. 1960. Microhaematocrit as a tool in fisheries management. Special scientific report - fisheries. No. 314 U.S. Department International Fish and Fisheries Wildlife Special Science, 15.

[53] Dacie, J.V., Lewis, S.M. 2001. Practical Haematology, 9th edn. Churchill Livingston, London 2001.

[54] Seiverd, C.E. 1983. Haematology for medical Technologists. Lea and Febiger, Philadelphia, USA, 946.

[55] Blaxhall, C.P. 1972. The haematological assessment of the health of freshwater fish. J Fish Biol, 4(4), 593-604.

[56] McCarty, D.H., Stevenson, J.P., Roberts, M.S. 1973. Some blood parameters of rainbow trout (Salmo gairdneri, Richardson). J Fish Biol, 5, $1-8$.

[57] Hickey, C.R. 1976. Fish hematology: its uses and significance. NY Fish Game J, 23, 170-75.

[58] Duthie, G.G., Tort, L. 1985. Effects of dorsal aortic cannulation on the respiration and haematology of Mediterranean living Scyliorhinus canicula. Comp. Biochem. Physiol., A, 81, 879-85.

[59] Praveena, M., Sandeep, V., Kavitha, N., Jayantha Rao, K. 2013. Impact of Tannery effluent, Chromium on hematological parameters in a freshwater fish, Labeo rohita (Hamilton). Res J Animal Veterinary and Fishery Sci, 1(6), 1-5.

[60] Senthamilselvan, D., Chezhian, A., Suresh, E., Ezhilmathy, R. 2012. Toxic effects of heavy metals (Cadmium plus mercury) on haematological parameters and DNA damage in Lates calcarifer.J Toxicol Environ Hlth Sci, 4(9), 151-161.

[61] Veeraiah, K., Srinvasa Rao, P., Symyuktha Rani, A., Dhilleswarao, H. 2013. Changes in biochemical parameters of freshwater fish Labeo rohita exposed to lethal and sublethal concentrations of Indoxacarb. Int J Bioass, 2(10), 1382-87.

[62] Parthipan, P., Muniyan, M., Samipillai, S.S. 2014. Effect of heavy metal Nickel on the biochemical parameters in the selected tissues of Cirrhinus mrigala (Ham.). Int J mod Res Revs, 2(4), 147-56.

[63] Raeisi, S., Alishahi, A.R., Pour, B.S., Jjagh, S.M., Rad, J.S., Iriti, M. 2015. Nutritional composition and antioxidant activity of Vobla- roach (Rutilus rutilus caspicus) muscle tissue exposed to heavy metals. Bull Environ Pharm Life Sci, 4(2), 83-90.

[64] Larsson, A. 1975. In: Sublethal effects of toxic chemicals on aquatic animals (Ed. Koeman, J.H. and Strik. J.J. T. W .A.). Elsevier. Sci. Publ. Co. Amsterdam, 3-13.

[65] Thomas, P., Bally, M., Neff, J.M. 1982. Ascorbic acid status of mullet, Mugil cephalus Linn. exposed to Cadmium. J Fish Biol, 20, 183-96.

[66] Joshi, P.K., Bose, M., Harish, D. 2002. Haematological changes in the blood of Clarias battrachus exposed to Mercuric chloride. Ecotoxicol Environ Monit, 12, 119-122.

[67] Pamila, D., Subbaiyan, P.A., Ramaswamy, M. 1991. Toxic effect of Chromium and Cobalt on Sartherodon mossambicus (peters). Ind. J. Environ. Hlth., 33, 218-24.

[68] Christensen, G.M., McKim, J.M., Burngs, W.A., Hunt, E.P. 1972. Changes in the blood of the brown bullhead (Ichtaiurus nebuloses) (Lesueur) following short and long term exposure to Copper (II) Toxicol Applied Pharmacol, 23, 417-27.

[69] Wepener, V., Van Vuren, J.H.J., Du Preez, H.H. 1992. Effect of manganese and iron at neutral and acidic $\mathrm{pH}$ on the haematology of banded tilapia (Tilapia sparrmanii). Bull Environ Contam Toxicol, 41, 92128.

[70] Nussey, G., Van Vuren, J.H.J., Du Preez, H.H. 1995. Effect of Copper on the haematology and osmoregulation of the Mozambique tilapia, Oreochromis mossambicus (Cichlidae). Comp Biochem Physiol Part C: Comp Pharmacol Toxicol, 111, 369-80.

[71] Shalaby, A.M.E. 2001. Protective effect of ascorbic acid against mercury intoxication in Nile tilapia (Oreochromius niloticus). J Egypt Acad Soc Environ Develop (D-Environ-Stud), 2(3), 79-97.

[72] Al-Attar, A.M. 2005. Changes in haematological parameters of the fish, Oreochromis niloticus treated with sublethal concentration of Cadmium. Pak J Biol Sci, 8, 421-24.

[73] Singh, D., Nath, K., Trivedi, S.P., Sharma YK. Impact of Copper on haematological profile of freshwater fish, Channa punctatus. J Environ Biol, 29(2), 253-57.

[74] Zutshi, B.S.G., Prasad, R., Nagaraja, R. 2010. Alteration in hematology of Labeo rohita under stress of pollution from Lakes of Bangalore, Karnataka, India. Environ Monit Assess, 168, 11-19.

[75] Sharma, J., Langer, S. 2014. Effect of Manganese on haematological parameters of fish, Garra gotyla gotyla. JEZS, 2(3), 77-81.

[76] Johansson-Sjöbeck, M.L., Larsson, A. 1978. The effects of Cadmium on the haematology and the activity of aminolevulinic acid dehydratase (ALA-D) in blood and haematopoietic tissues of the flounder Pleuronectes flesus L. Environ Res, 17, 191-204.

[77] Mishra, S., Srivastava, A.K. 1980. The acute toxic effects of Copper on the blood of a teleost. Ecotoxicol Environ Saf, 4, 191-94.

[78] Vijayaram, K., Geraldine, P., Varadarajan, T.S., John, G., Loganathan, P. 1989. Cadmium induced changes in the biochemistry of an air breathing fish, Anabas scandeus. J Eco Biol, 1, 245-51.

[79] Tort, L., Hernandez-Pascual, M.D. 1990. Haematological effects in dogfish Scyliorhinus canicula after short-term sublethal Cadmium exposure. Acta Hydrochimica et Hydrobiol, 18, 379-383.

[80] Nath, R., Banerjee, V. 1995. Effects of various concentrations of lead nitrate on haematological parameters of an air breathing fish, Clarias batrachus. J Freshwater Biol, 7, 267-68.

[81] Mazon, A.F., Monteiro, E.A., Pinheiro, G.H., Fernandes, M.N. 2002. Hematological and physiological changes induced by short-term exposure to Copper in the freshwater fish, Prochilodus scrofa. Braz J Biol, 62, 621-31.

[82] Siakpere, K.O., Ikomi, U. 2011. Alterations in some haematological parameters of the African Snakehead Parachana africans exposed to Cadmium. Not Sci Biol, 3(4), 29-34.

[83] Raina, S., Sachar, A. 2014. Effect of heavy metal, Zinc and Carbamate pesticide, Sevin on haematological parameters of fish, Labeo boga. Int J Innov Res Sci Eng Tech, 3(5), 12636- 644.

[84] Mukherjee, S., Ray, D., Adhikari, D., Ghosh, T. 2015. Impairment of haematological profile of Channa punctatus exposed to Sodium arsenite. Int J App Biol Pharma Tech, 6(2), 223-29.

[85] Moosavi, M.J., Shamushaki, V.A.J. 2015. Effect of sub-acute exposure to Nickel on hematological and biochemical indices in gold fish (Carassius auratus). J Clin Toxicol, 5, 1-5.

[86] Shekar, P., Christy, I. 1996. Haematological changes in the fresh water cat fish Mystus vittatus, exposed to sublethal concentrations of Phosphamidon. J Ecol, 8(1), 25-28.

[87] Wintrobe, M.M. 1978. Clinical Haematology. H. Kimpton, London, U.K, 488. 
[88] Lowe, J., Nimmi, A.J. 1986. Haematological characterization of rainbow trout Salmo gairdneri in response to Cd exposure. Bull Environ Toxicol, 37, 375 .

[89] Houston, A.H., Keen, J.E. 1984. Cadmium inhibition of erythropoiesis in goldfish, Carassius auratus. Canad J Fish Aqua Sci, 41, 1829-834.

[90] Gill, T.S., Epple, A. 1993. Stress-related changes in the hematological profile of the American eel (Anguilla rostrata). Ecotoxicol Environ Saf, 25(2), 227-35.

[91] Smit, G.L., Hattingh, J., Burger, A.P. 1979. Haematological assessment of the effects of the anaesthetic MS222 in natural and neutralized from in three freshwater fish species: interspecies differences. J Fish Biol, 15, 63343.

[92] Goel, K.A., Gupta, K., Sharma, M.L. 1985. Haematological characteristics of Heteropneustes fossilis under the stress of Zinc. Ind J Fish, $36,186-188$
[93] Goel, K.A., Sharma, S.D. 1987. Some haematological characteristics of Clarias batrachus under metallic stress of Arsenic. Comp Physiol Ecol 12, 63-67.

[94] Musa, S.O., Omoregie, E. 1999. Haematological changes in Clarias gariepinus exposed to Malachite green. J Aqua Sci, 14, 37-42.

[95] Sinha, A.K., Sinha, M.K., Adhikari, S. Effect of the copper toxicity on haematological profile of Indian major carp, Labeo rohita. Hand book Indus Environ and Poll, 166-172.

[96] Afaq, S., Rana, K.S. 2009. Toxicological effects of leather dyes on total leulocyte count of freshwater teleost, Cirrhinus mrigala (Ham). Biology and Medicine, 1(2), 134-38.

[97] Jastrzebska, E.B., Protasowickiz, M. 2005. Effects of cadmium and nickel exposure on hematological parameters of common carp, Cyprinus carpio L. Acta Ichthyol Piscat, 35(1), 29-38.

Table 1: Haematological profiles of Cyprinus carpio var. koi exposed to sublethal concentration of $\mathrm{CdCl}_{2}$

\begin{tabular}{|c|c|c|c|c|c|c|}
\hline \multirow{3}{*}{ Haematological profiles } & \multicolumn{6}{|c|}{ Exposure periods } \\
\hline & \multicolumn{3}{|c|}{15 Days } & \multicolumn{3}{|c|}{30 Days } \\
\hline & Control & Treatment & $\%$ changed & Control & Treatment & $\%$ changed \\
\hline $\mathrm{Hb}(\mathrm{g} / \mathrm{dl})$ & $8.40 \pm 0.10$ & $7.50 \pm 0.10^{*}$ & -10.71 & $10.20 \pm 0.20$ & $5.36 \pm 0.05^{*}$ & -47.45 \\
\hline $\begin{array}{l}\text { WBC (thousand } \\
\text { cells } / \mathrm{mm}^{3} \text { ) }\end{array}$ & $1.69 \pm 0.02$ & $2.19 \pm 0.05^{*}$ & 29.58 & $1.87 \pm 0.01$ & $3.16 \pm 0.01 *$ & 68.98 \\
\hline $\begin{array}{l}\text { RBC (million } \\
\text { cells } / \mathrm{mm}^{3} \text { ) }\end{array}$ & $1.49 \pm 0.01$ & $1.21 \pm 0.02 *$ & -18.79 & $2.10 \pm 0.1$ & $0.88 \pm 0.01^{*}$ & -58.09 \\
\hline PCV (\%) & $10.46 \pm 0.15$ & $8.43 \pm 0.11^{*}$ & $-19.40 \%$ & $12.62 \pm 0.01$ & $6.27 \pm 0.05^{*}$ & -50.31 \\
\hline $\operatorname{MCV}(\mathrm{fl})$ & $82.36 \pm 0.01$ & $84.63 \pm 0.02 *$ & 2.75 & $85.23 \pm 0.01$ & $88.36 \pm 0.01 *$ & 3.67 \\
\hline $\mathrm{MCH}(\mathrm{pg})$ & $32.84 \pm 0.01$ & $30.22 \pm 0.01 *$ & -7.97 & $35.48 \pm 0.005$ & $27.62 \pm 0.02 *$ & -22.15 \\
\hline MCHC (\%) & $40.66 \pm 0.01$ & $39.77 \pm 0.01 *$ & -2.18 & $44.56 \pm 0.02$ & $37.50 \pm 0.2^{*}$ & -15.84 \\
\hline $\operatorname{PLT}\left(10^{9} / \mathrm{l}\right)$ & $5.95 \pm 0.01$ & $3.96 \pm 0.05^{*}$ & -33.44 & $7.87 \pm 0.011$ & $3.53 \pm 0.015^{*}$ & -55.14 \\
\hline
\end{tabular}

C: Control, T: exposed. Values are expressed as Mean \pm SD of ten individual observations, -: Percent decrease over control, * indicates significant changed at $\mathrm{P}<0.05$. 